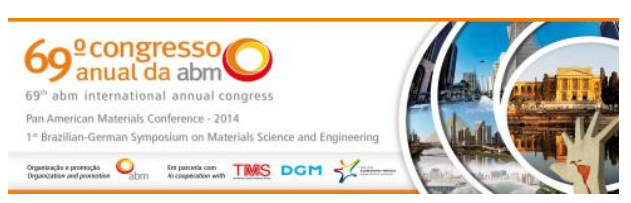

Tema: Metalurgia física e comportamento de materiais em temperaturas elevadas

\title{
CHARACTERIZATION OF A NEW LOW MANGANESE, NIOBIUM MICROALLOYED STEEL FOR SOUR SERVICE*
}

\author{
Mario González Ramírez ${ }^{1}$ \\ Neusa Alonso Falleiros ${ }^{2}$ \\ Hélio Goldenstein ${ }^{3}$
}

Frank Barbaro 4

\begin{abstract}
The safe transport of sour gas requires steels with enhanced hydrogen induced cracking (HIC) resistance. Centerline segregation bands of high hardness microconstituents and non-metallic inclusions are the heterogeneities usually linked to HIC failures in pipeline steels. Full-scale production heats of a new low $\mathrm{Mn}, \mathrm{Nb}$ microalloyed steel were produced by different steel mills aiming at the application in sour gas environments. The new alloy design provides both effective strengthening and control of sulphide inclusions. Coil microstructure consisted of fine grained ferrite with a small volume fraction of uniformly dispersed eutectoid aggregates. Most importantly the microstructure was uniform in both the longitudinal and transverse directions and exhibited exceptional consistency. Samples from this steel were submitted to HIC testing according to NACE standards TM0284-2003 without any sign of cracking. The results, so far, confirm that this new alloy design provides the unique opportunity to economically produce a high strength pipe steel grade with improved sour service resistance for the linepipe industry.
\end{abstract}

Keywords: HIC; API 5L; Sour service; $\mathrm{H}_{2} \mathrm{~S}$; Nb microalloy; Low Mn.

1 Doutor em Engenharia, Departamento de Engenharia Metalúrgica e de Materiais, EPUSP, São Paulo, SP, Brasil.

2 Professora Doutora, Departamento de Engenharia Metalúrgica e de Materiais, EPUSP, São Paulo, SP, Brasil.

3 Professor Titular, Departamento de Engenharia Metalúrgica e de Materiais, EPUSP, São Paulo, $S P$, Brasil.

4 Doutor em Engenharia, Professor da Universidade de Wollongong, Consultor da Companhia Brasileira de Metalurgia e Mineração (CBMM), Austrália.

\footnotetext{
* Contribuição técnica ao $69^{\circ}$ Congresso Anual da ABM - Internacional e ao 14ํㅡㄹ ENEMET - Encontro Nacional de Estudantes de Engenharia Metalúrgica, de Materiais e de Minas, 21 a 25 de julho de 2014, São Paulo, SP, Brasil.
} 


\section{INTRODUCTION}

New designs in high strength low alloy steels (HSLA) are being demanded to attend new conditions of gas and oil transportation. The use of novel steelmaking and casting processes associated with new thermo mechanical control process (TMCP) and accelerated cooling, permit obtaining ultra clean slabs with low hydrogen, low porosity and minimal centerline segregation for pipeline manufacturers [1].

This new low Mn HSLA steel concept is designed to work in acidic environments containing $\mathrm{H}_{2} \mathrm{~S}$, resisting hydrogen induced cracking $(\mathrm{HIC})$. The composition of this new low $\mathrm{Mn}, \mathrm{Nb}$ microalloyed steel includes reduced levels of $\mathrm{C}, \mathrm{Mn}, \mathrm{S}, \mathrm{P}, \mathrm{N}$ and $\mathrm{Ca}$ to minimize the centerline segregation [1,2]. Sulfur $(<0.002 \%)$ and manganese $(<0.27 \%)$ levels were lowered to improve the control of MnS inclusions. Additionally, Mn reduction improved the hot rolling practices, raising the temperature of austenite to ferrite transformation [2,3].

HIC resistance is usually associated with high concentration of elements on the centerline, forming non-metallic inclusions as MnS in conjunction with coarse segregation bands. As is well known, segregation bands and non-metallic inclusion are the main causes of hydrogen induced cracking (HIC) $[4,5]$.

The present research describes the results of microstructural characterization, mechanical properties and HIC tests (NACE TM 0284), on a coil sample of a low Mn microalloyed steel with ultra low segregation, intended for severe sour service conditions.

\section{EXPERIMENTAL AND PROCEDURES}

The microalloyed steel was received as $9.5 \mathrm{~mm}$ thickness coil. Chemical composition is showed in Table 1.

Table 1 - Chemical Composition of the studied steel (weight \%) Include Pcm value as well

\begin{tabular}{|c|c|c|c|c|c|c|c|c|c|c|c|}
\hline $\begin{array}{c}\mathrm{C} \\
(\%)\end{array}$ & $\begin{array}{c}\mathrm{Si} \\
(\%)\end{array}$ & $\begin{array}{c}\mathrm{Mn} \\
(\%)\end{array}$ & $\mathrm{P}(\%)$ & $\begin{array}{c}\mathrm{S} \\
\mathrm{ppm}\end{array}$ & $\mathrm{Cr}(\%)$ & $\begin{array}{c}\mathrm{Ni} \\
(\%)\end{array}$ & $\begin{array}{c}\mathrm{Cu} \\
(\%)\end{array}$ & $\begin{array}{c}\mathrm{Ti} \\
(\%)\end{array}$ & $\begin{array}{c}\mathrm{Nb} \\
(\%)\end{array}$ & $\begin{array}{c}\mathrm{Al} \\
(\%)\end{array}$ & $\begin{array}{c}\mathrm{Ca} \\
\mathrm{ppm}\end{array}$ \\
\hline 0,046 & 0,16 & 0,27 & 0,011 & $<20$ & 0,47 & 0,15 & 0,28 & 0,014 & 0,082 & 0,032 & 5 \\
\hline
\end{tabular}

Optical and scanning electron microscopy, EDS and microhardness were used to characterize the steel microstructure. Hydrogen induced cracking $(\mathrm{HIC})$ tests were conducted according to TM0284 NACE Standard [6]. The steel mechanical properties have been characterized by Charpy impact tests and tensile tests. The items below summarize the procedures used in such tests.

\subsection{Hydrogen Induced Cracking}

Test specimens for HIC tests were longitudinal to the rolling direction of the coil containing the full coil thickness, as indicated by the NACE TM-0284 standard. The five specimens tested were sectioned every $25 \mathrm{~mm}$; the surface of each transverse section was polished to $1 \mu \mathrm{m}$ and examined with optical microscopy and SEM for the identification of possible cracks.

\footnotetext{
* Contribuição técnica ao $69^{\circ}$ Congresso Anual da ABM - Internacional e ao 14ํㅡㄹ ENEMET - Encontro Nacional de Estudantes de Engenharia Metalúrgica, de Materiais e de Minas, 21 a 25 de julho de 2014, São Paulo, SP, Brasil.
} 


\subsection{Charpy Impact}

Charpy impact tests were conducted according with API 5L-2004 and ASTM A370 [7] standard. The Charpy $\mathrm{V}$-notch test specimens were transverse to the rolling direction, which is the most critical orientation regarding Charpy impact strength. Due to the coil thickness of $9.5 \mathrm{~mm}$, subsize specimens $(7.5 \times 10 \times 55 \mathrm{~mm})$ have been used. In order to compare the absorbed energy of subsize specimens (Esub) with the energy obtained from standard specimens (Estd), Esub was divided by the ratio of the tested specimen thicknesses to the full size specimen thickness (API 5L-SR5B.3 -2004) as follows in Equation 1:

$$
E s t d=\operatorname{Esub} / \frac{7,5 \mathrm{~mm}}{10 \mathrm{~mm}}
$$

Tests were carried out using a $300 \mathrm{~J}$ impact energy Charpy testing machine at a temperature of $32^{\circ} \mathrm{F}\left(0^{\circ} \mathrm{C}\right)$, six test specimens have been used. The measured energies from the subsize test specimens on transverse direction were compared with the acceptance criteria for standard test specimens on similar orientation according to API-5L 2004.

\subsection{Tensile Test}

All tensile test specimens were machined according to standard API 5L-2004 with subsize dimensions. Six specimens were tested in both the longitudinal and transverse direction. The axial direction of test samples contained the centerline of the coil thickness. The tensile tests were carried out using a TIME $100 \mathrm{KN}$ Universal Testing Machine, at a strain rate of $1 \mathrm{~mm} / \mathrm{min}$ according to ASTM A370 standard [7] and deformation was measured with a $25 \mathrm{~mm}$ extensometer. Table 2 shows the values required by the standard API 5L-2004.

Table 2. Mechanical properties required by the standard API 5L-2004.

\begin{tabular}{ccccc}
\hline Material & $\begin{array}{c}\text { Yield } \\
\text { Strength } \\
\text { Min. }\end{array}$ & $\begin{array}{c}\text { Yield Strength } \\
\text { Max. }\end{array}$ & $\begin{array}{c}\text { Strength } \\
\text { Min }\end{array}$ & $\begin{array}{c}\text { Strength } \\
\text { Max. }\end{array}$ \\
\hline \hline X65 & $65.000(448)$ & $87.000(600)$ & $77.000(531)$ & $110.000(758)$ \\
X70 & $70.000(483)$ & $90.000(621)$ & $82.000(565)$ & $110.000(758)$ \\
\hline
\end{tabular}

\section{RESULTS AND DISCUSION}

\subsection{Microstructural Examination - OM}

Figure 1a shows the microstructure by optical microscopy (OM) through the coil thickness of $9.5 \mathrm{~mm}$. The microstructure in the through thickness on the rolling direction $(\mathrm{RD})$ revealed uniform grain refinement in both the upper and lower regions (Figures 1a to e). Higher magnification observations in the centerline region using OM showed isolated pockets of what is believed to be submicron precipitates.

The microstructure through the thickness was free of any segregation bands and the matrix consisted predominantly of quasi-polygonal ferrite grains. Few and small dark islands of eutectoid aggregates were randomly distributed in the matrix.

\footnotetext{
* Contribuição técnica ao $69^{\circ}$ Congresso Anual da ABM - Internacional e ao 14ํㅡㄹ ENEMET - Encontro Nacional de Estudantes de Engenharia Metalúrgica, de Materiais e de Minas, 21 a 25 de julho de 2014, São Paulo, SP, Brasil.
} 


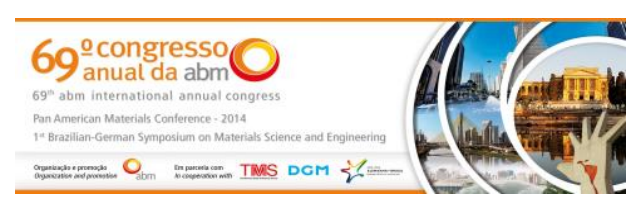

Figure 2 presents the micro-hardness profile along the coil thickness measured with $0.5 \mathrm{~mm}$ steps. The hardness was homogeneous along the thickness with only a slight variations which occurred around the centerline region. The average hardness along the coil thickness was $188 \pm 6$ HV0,3, with maximum hardness 199 HV0.3. The significant point to note from Figure 2 is the overall uniform hardness and the absence of any hardness peak, particularly at the centreline region. Selective hardness measurements of the centerline was able to reveal slight increases in hardness which is thought to be associated with micro bands of segregate.

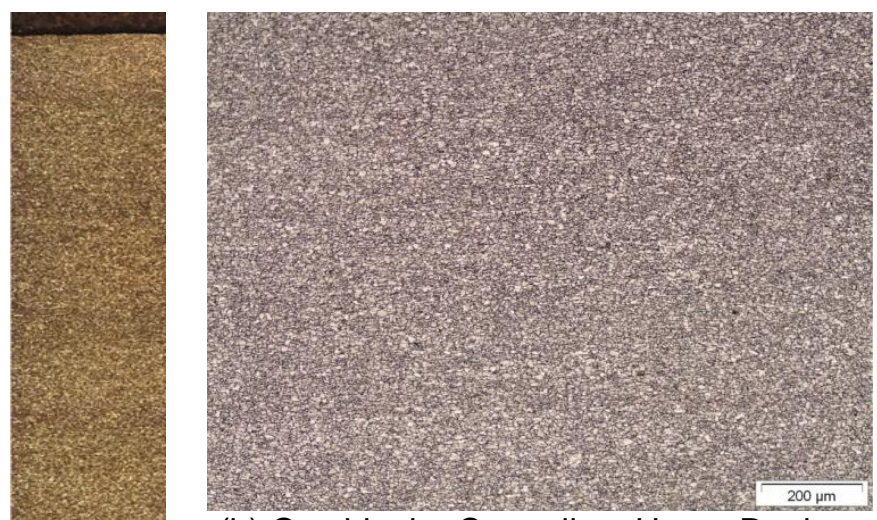

(b) Outside the Centerline. Upper Region. $100 X$

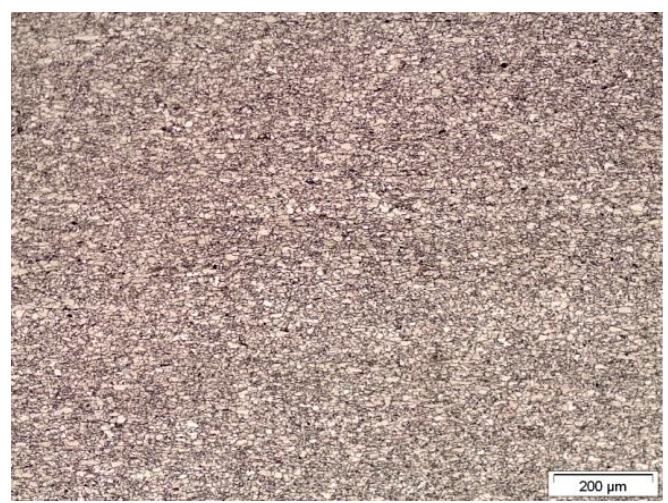

(d) Centerline Region. 100X

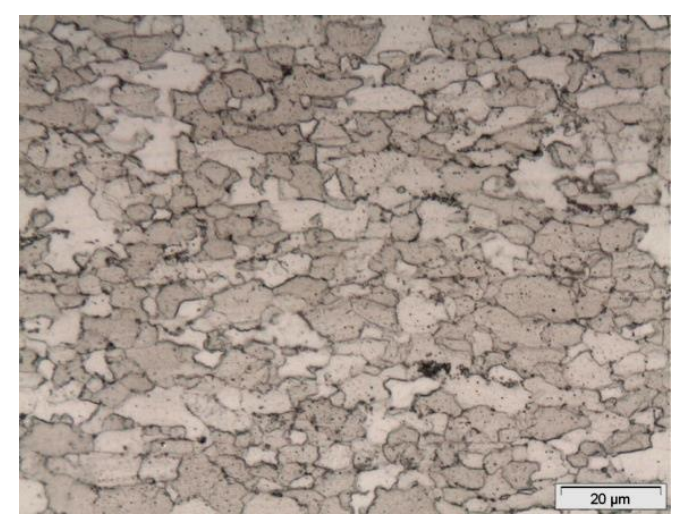

(c) Typical microstructure outside the Centerline. Upper Region. 1000X

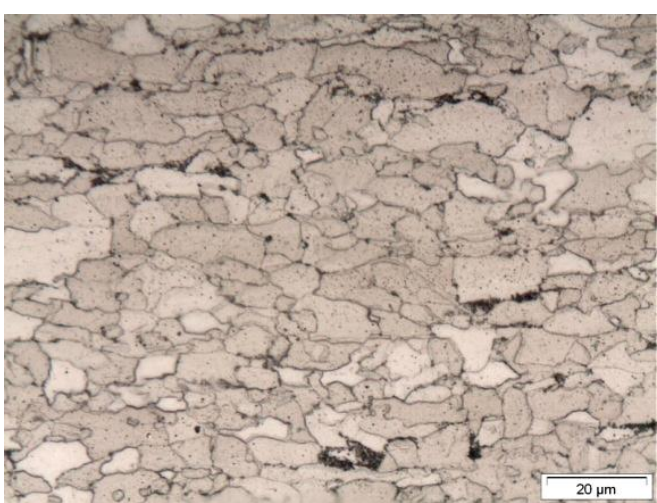

(e) Centerline Region. 1000X

Lower Region

(a)

Figure 1. Microstructure along the plate thickness of $9.5 \mathrm{~mm}$. OM. 100X. Nital $2 \%$.

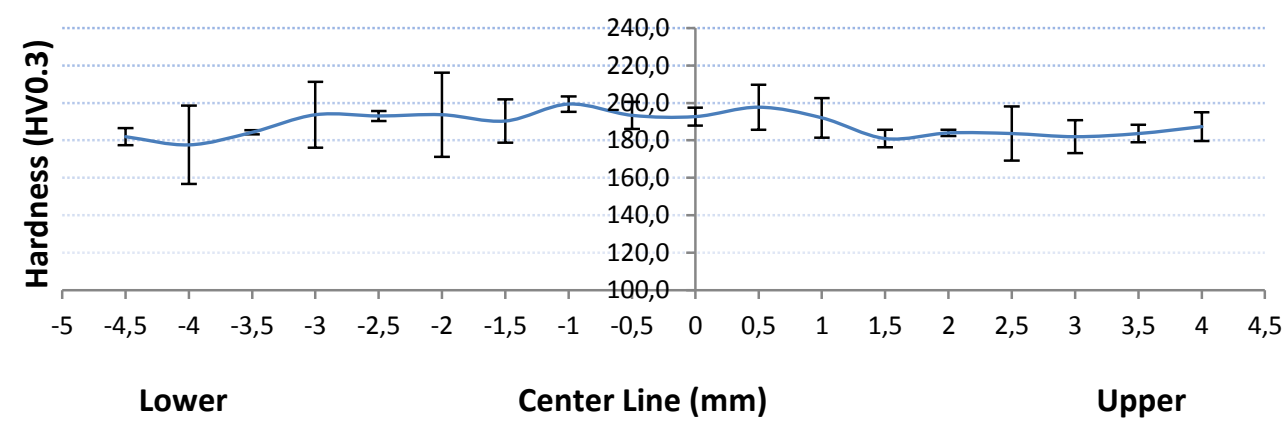

Figure 2. Hardness profile along the coil thickness.

* Contribuição técnica ao 69 Congresso Anual da ABM - Internacional e ao 14ํㅡㄹ ENEMET - Encontro Nacional de Estudantes de Engenharia Metalúrgica, de Materiais e de Minas, 21 a 25 de julho de 2014, São Paulo, SP, Brasil. 


\subsection{Microstructural Examination by SEM}

The microstructure obtained was mostly composed of quasi-polygonal refined grains of ferrite $(\sim 7 \mu \mathrm{m})$ with small islands of eutectoid aggregates (ferrite+cementite) homogeneously distributed in the matrix (Figure $4 \mathrm{a}$ to $\mathrm{h}$ ). The centerline does not present banded structures, only a thin line has been observed on the rolling direction (Figure $4 \mathrm{a}$ and $4 \mathrm{c}$ ). Outside the centerline no segregation marks have been observed (Figure $4 \mathrm{~b}$ and $4 \mathrm{~d}$ ). Another phase identified as Martensite - Austenite (MA) microconstituent was homogeneously distributed within the microstructure, mainly located on ferrite grain boundaries (Figure $4 \mathrm{~g}$ and $4 \mathrm{~h}$ ).

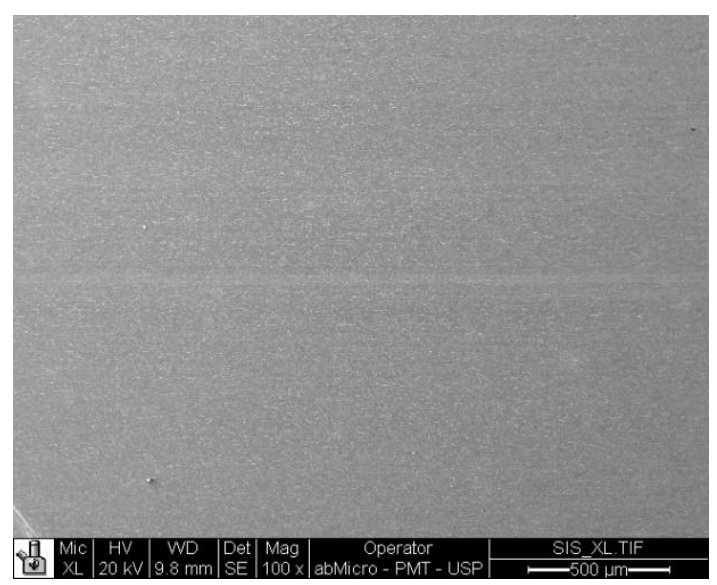

(a) Centerline

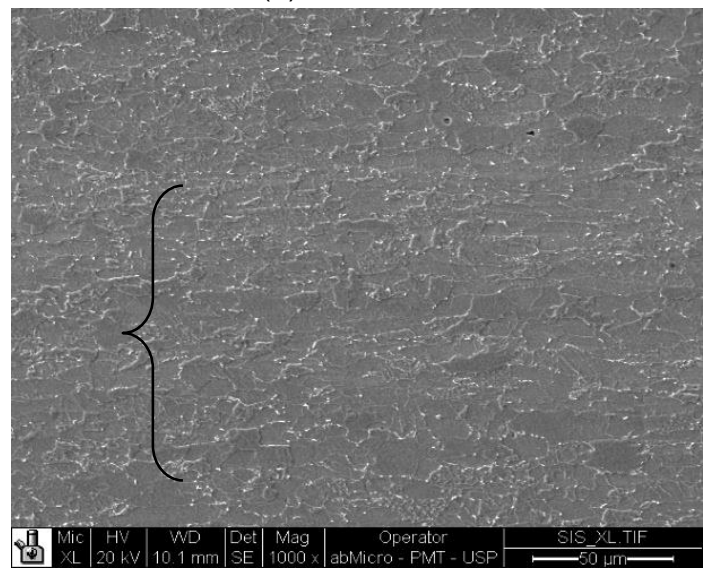

(c) Centerline

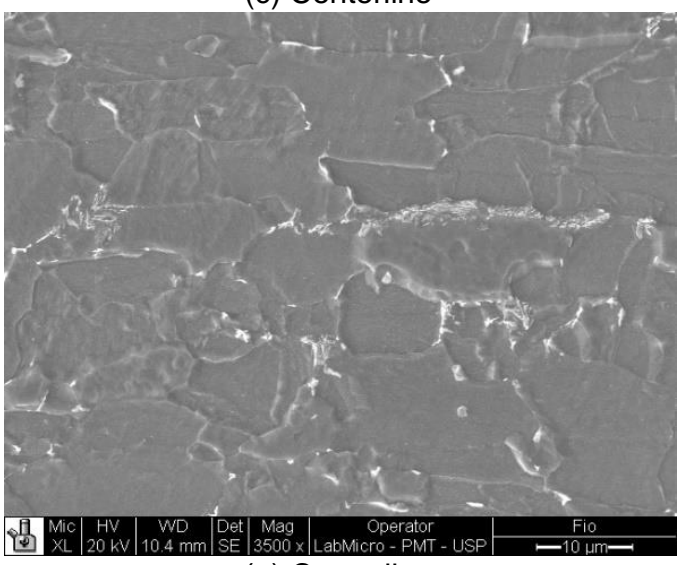

(e) Centerline

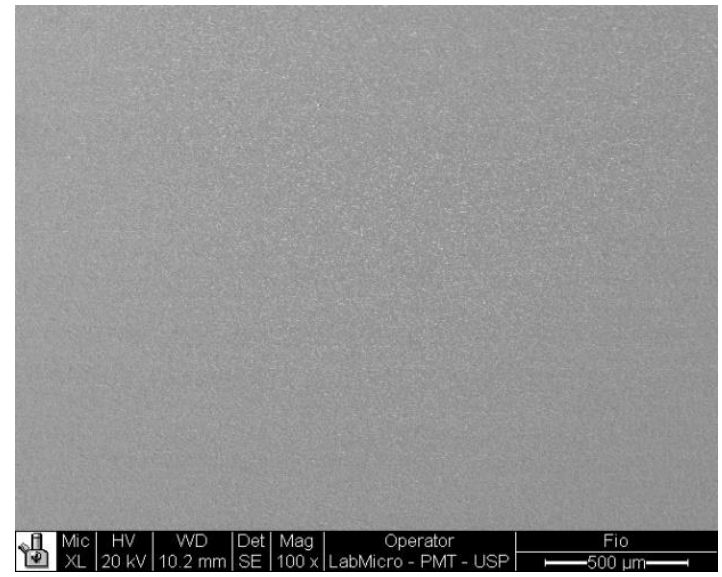

(b) Outside the centerline

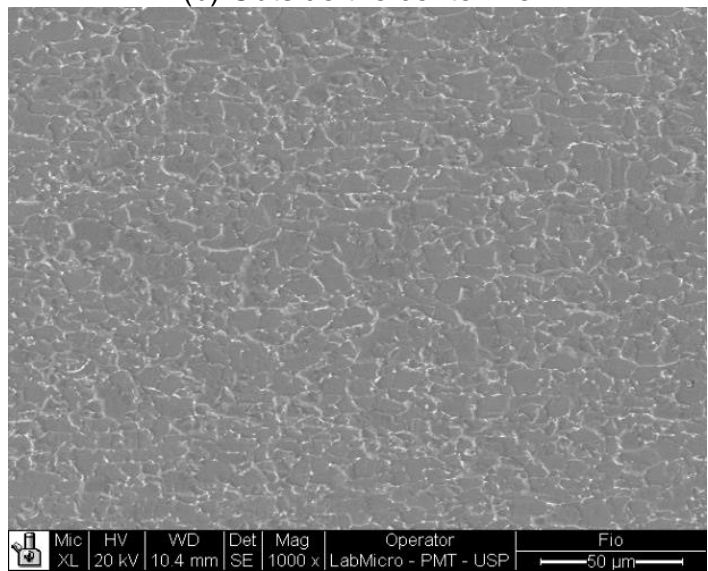

(d) Outside the centerline

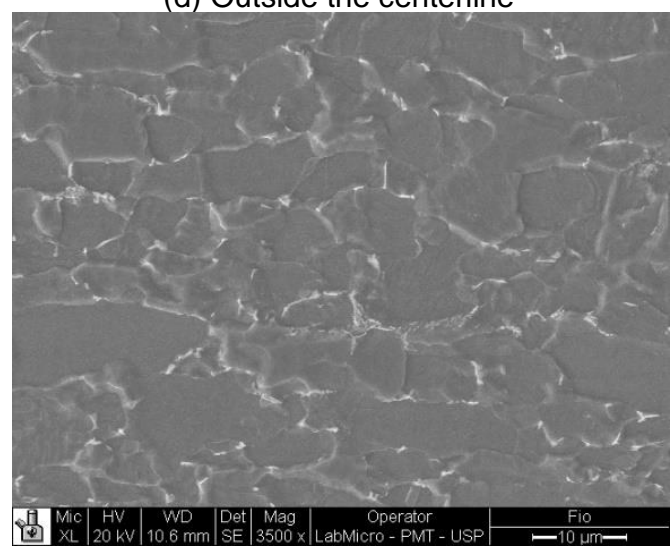

(f) Outside the centerline

* Contribuição técnica ao 69 Congresso Anual da ABM - Internacional e ao 14ํㅡㄹ ENEMET - Encontro Nacional de Estudantes de Engenharia Metalúrgica, de Materiais e de Minas, 21 a 25 de julho de 2014, São Paulo, SP, Brasil. 


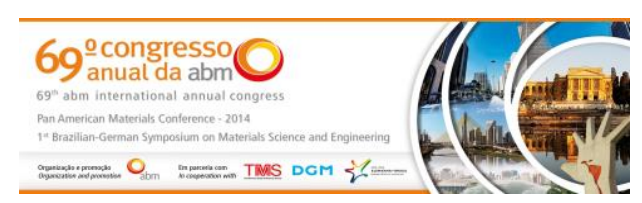

\subsection{Characterization of Inclusions and Precipitates}

The precipitates and inclusions were characterized with magnifications between $3500 \mathrm{X}$ and $25000 \mathrm{X}$ (figure $8 \mathrm{~b}$ and $8 \mathrm{c}$ ) on the rolling direction. Micrometrics precipitates shown in Figure $8 \mathrm{c}$ have been identified by EDS as ( $\mathrm{Nb}, \mathrm{Ti}) \mathrm{C}$ (Figure $8 \mathrm{~d}$ ). Figure $8 \mathrm{e}$ and $8 \mathrm{~g}$ show different types of inclusions identified by the EDS spectra shown on Figure $8 \mathrm{f}$ and $8 \mathrm{~h}$. These inclusions were observed mainly on the centerline of the coil thickness. Al-O-Ca oxides showed globular shapes with maximum diameter of $5 \mu \mathrm{m}$. Small precipitates and inclusions, outside the centerline were located randomly and in low quantities in the ferrite matrix.

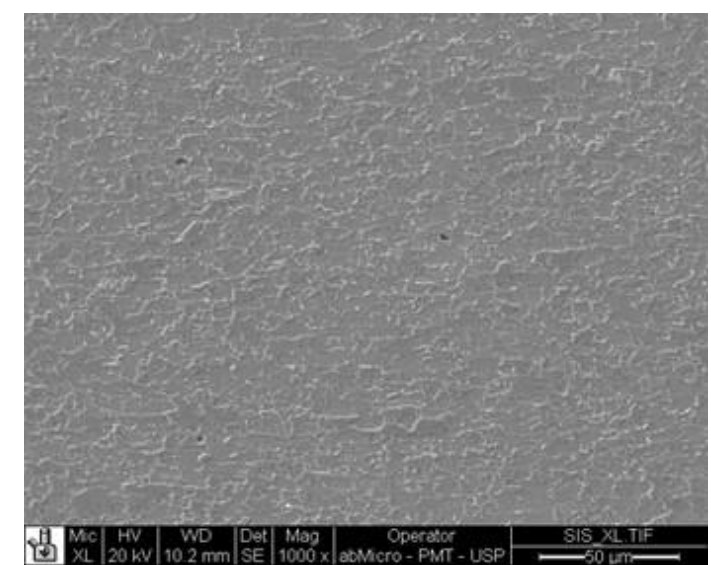

(a)

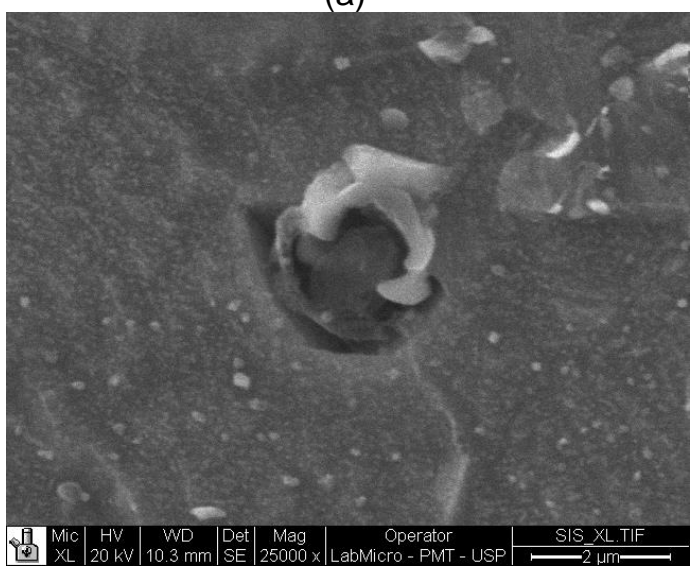

(c)

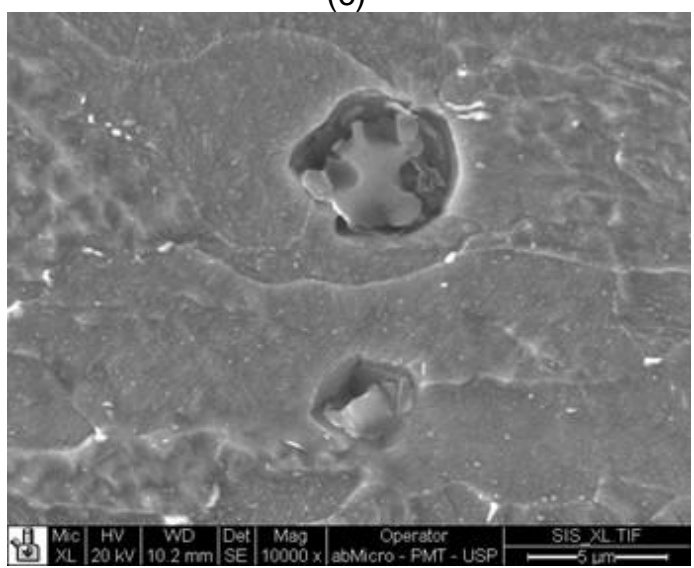

(e)

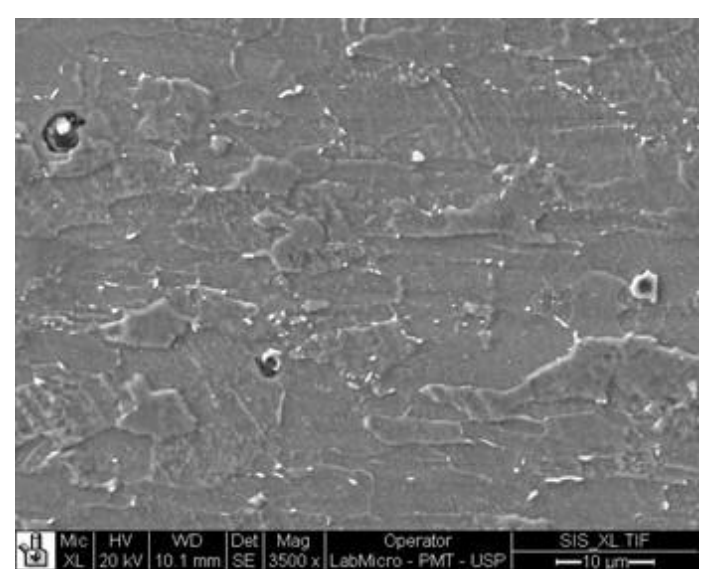

(b)

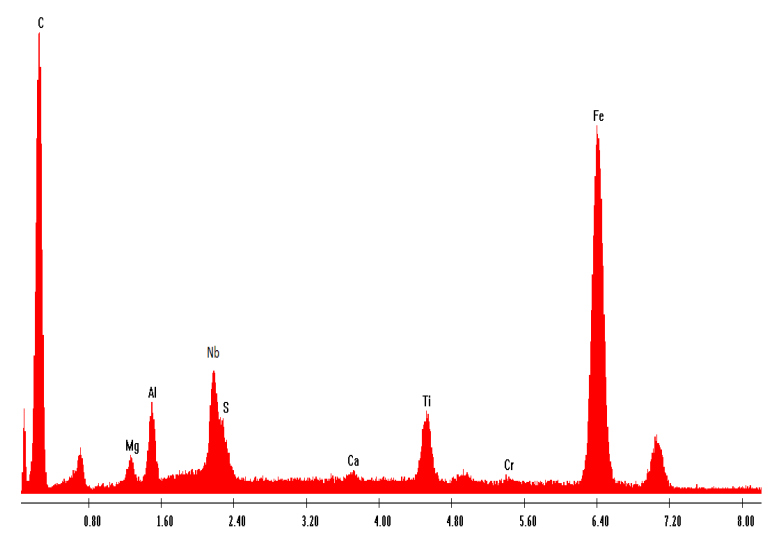

(d)

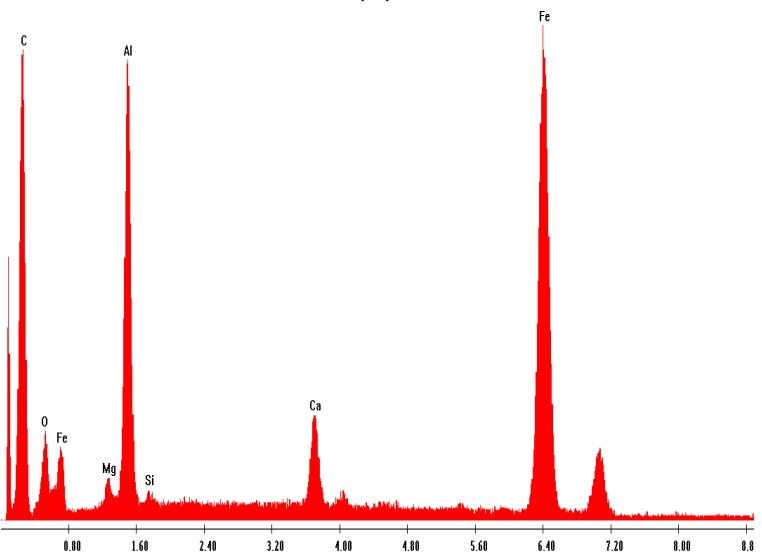

(f)

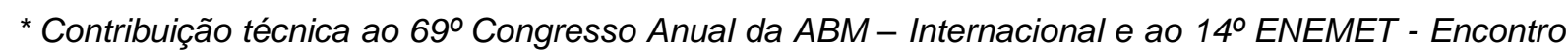
Nacional de Estudantes de Engenharia Metalúrgica, de Materiais e de Minas, 21 a 25 de julho de 2014, São Paulo, SP, Brasil. 


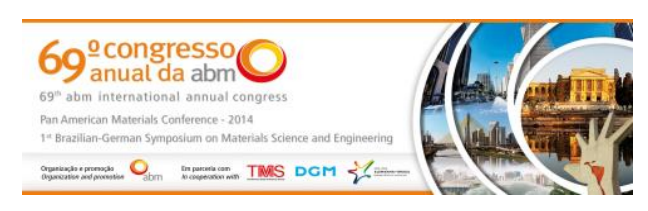

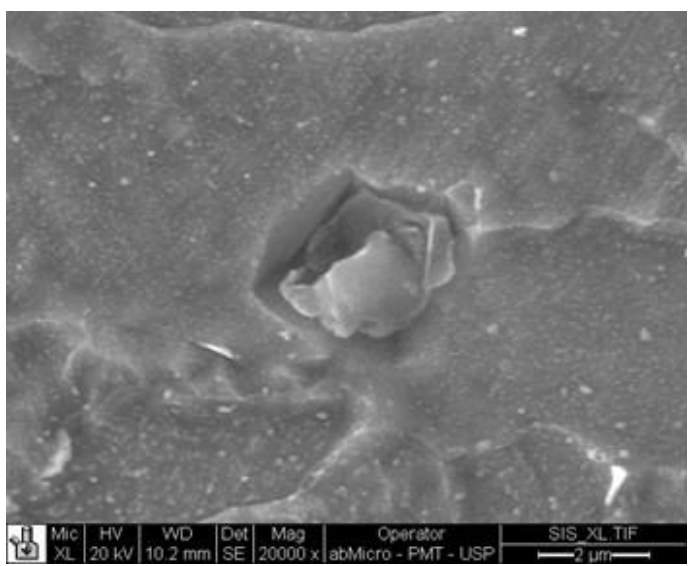

(g)

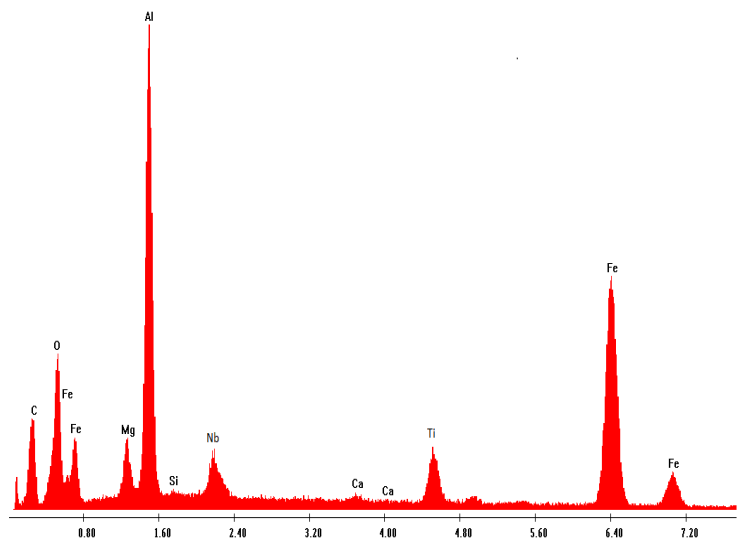

(h)

Figure 8. Precipitates and inclusions characterized by EDS-SEM.

\subsection{Hydrogen Induced Cracking Tests}

Specimens for HIC tests were extracted along the RD (ie longitudinal) and after the test showed black color indicating that they suffered corrosion in the presence of $\mathrm{H}_{2} \mathrm{~S}$. Following the 96 hour of imersion, the test specimens showed no cracks along the thickness on the fifty transverse surfaces examined, as shown in the Figure 9a.

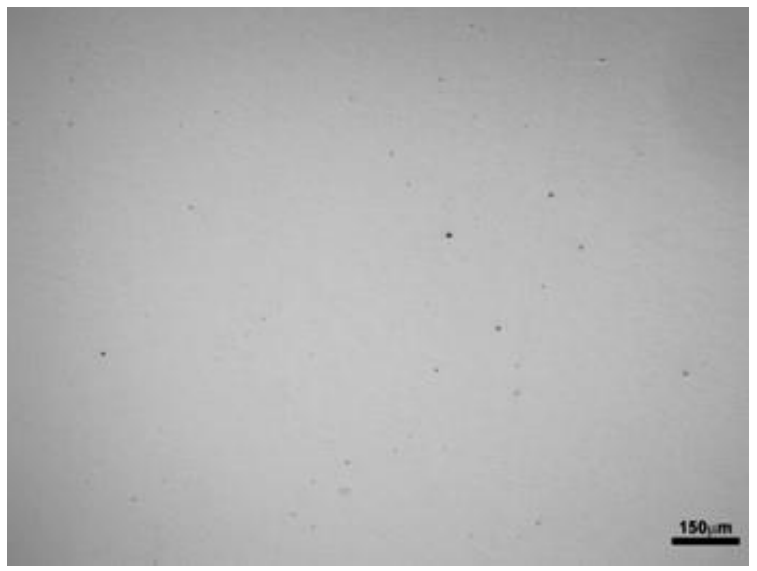

(a) OM. $100 \mathrm{X}$

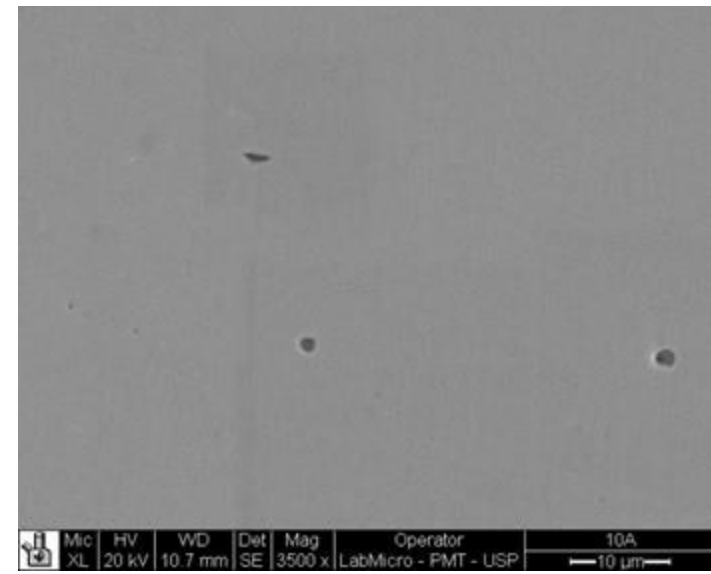

(b) SEM.

Figure 9. Micrographys of transverse sections without attack of test specimens after HIC test. (a) OM and (b) steel inclusions after HIC tests; SEM. NACE Standard TM-0284.

Examination with higher magnifications, using SEM, showed that the inclusions have not nucleated micro-cracks and had not had their boundaries damaged by the hydrogen presence (Figure 9b).

\subsection{Charpy Tests}

Charpy impact tests were carried out according with standard API 5L-2004 on subsize specimens on transverse direction. Table 2 shows the data obtained in the tests, the average energy absorbed (Estd) calculated by Equation 1 was $338 \pm 30 \mathrm{~J}$, higher than the energy in the acceptance criteria for standard test specimens at $0^{\circ} \mathrm{C}$ (API-5L 2004) (Table 1).

Figure 10 shows some fractured surfaces after the Charpy tests. Five specimens did not fracture completely and only the specimen number two broke into two parts. The

* Contribuição técnica ao 69 Congresso Anual da ABM - Internacional e ao 14ํㅡㄹ ENEMET - Encontro Nacional de Estudantes de Engenharia Metalúrgica, de Materiais e de Minas, 21 a 25 de julho de 2014, São Paulo, SP, Brasil. 


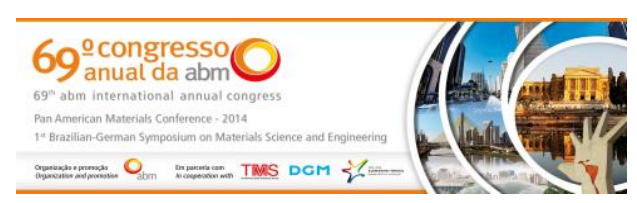

test specimens showed intense plastic deformation across the start and end fracture surface.

Table 2. Absorbed Energies on Charpy Tests carried out at $0^{\circ} \mathrm{C}$

\begin{tabular}{|c|c|c|c|}
\hline Sample & $\begin{array}{l}\text { Sub-size } \\
\text { Esub (J) }\end{array}$ & $\begin{array}{l}\text { Sub-size } \\
\text { factor }\end{array}$ & $\begin{array}{l}\text { Standard } \\
\text { Estd }(\mathrm{J})\end{array}$ \\
\hline 1 & 228 & 0.75 & 304 \\
\hline 2 & 289 & 0.75 & 385 \\
\hline 3 & 262 & 0.75 & 349 \\
\hline 4 & 232 & 0.75 & 309 \\
\hline 5 & 251 & 0.75 & 335 \\
\hline 6 & 258 & 0.75 & 344 \\
\hline Average & 253 & 0.75 & 338 \\
\hline
\end{tabular}

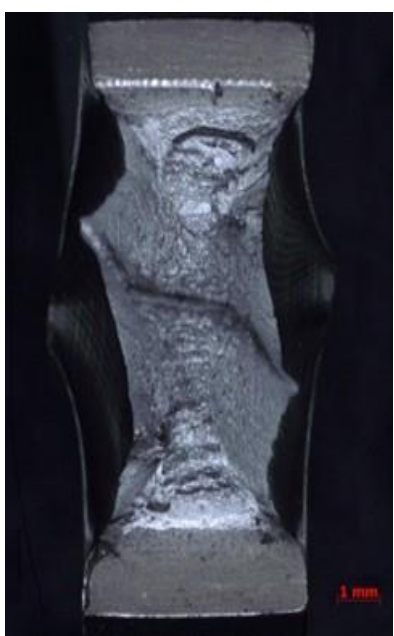

1

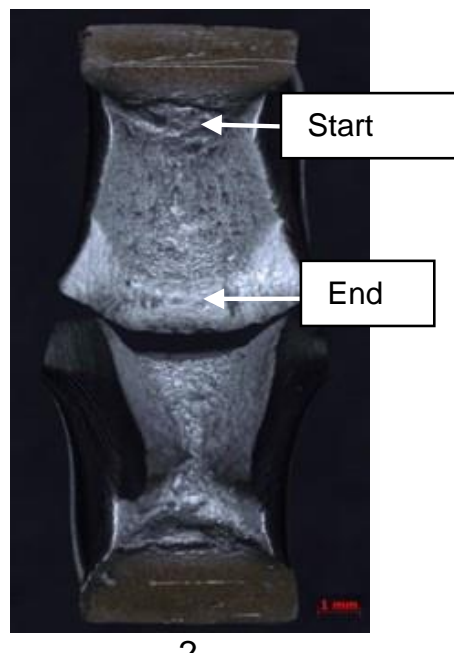

2

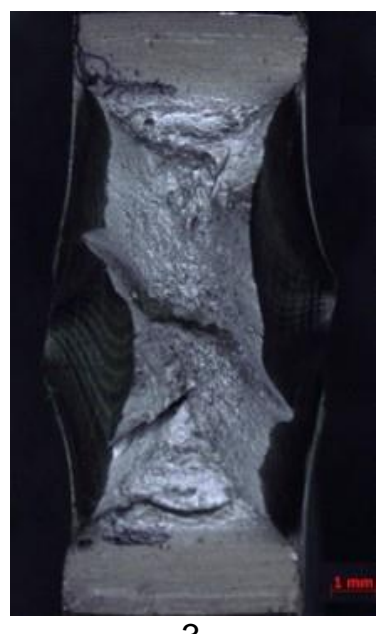

3

Figure 10. Subsize test specimens cracks after the Charpy impact tests $0^{\circ} \mathrm{C}$.

Figure 11a shows the crack initiation region (near the $\mathrm{V}$-notch) and figure 11c shows the end of the crack; SEM micrographs revealed the formation of dimple cavities across the fracture surface without presence of cleavage fracture_(Figure $11 \mathrm{~b}$ and 11d). All Charpy fractures section showed severe plastic deformation, with typical microvoid coalescence characteristic of ductile fracture.

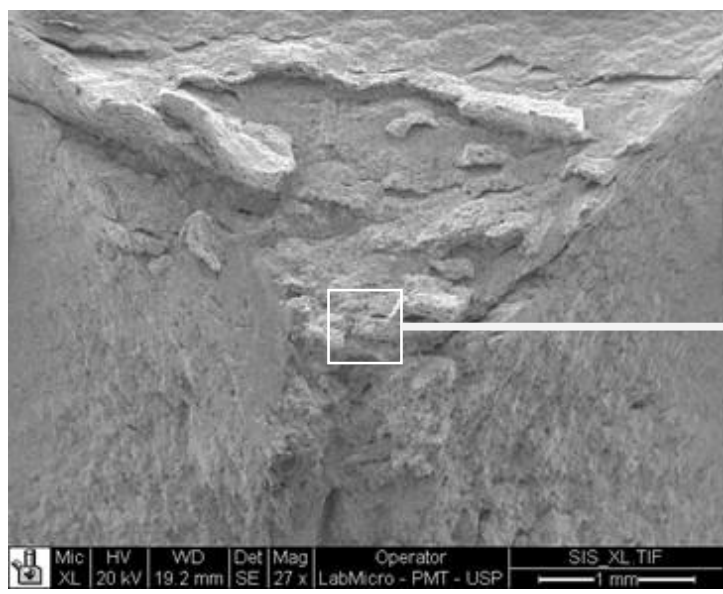

(a) Crack initiation

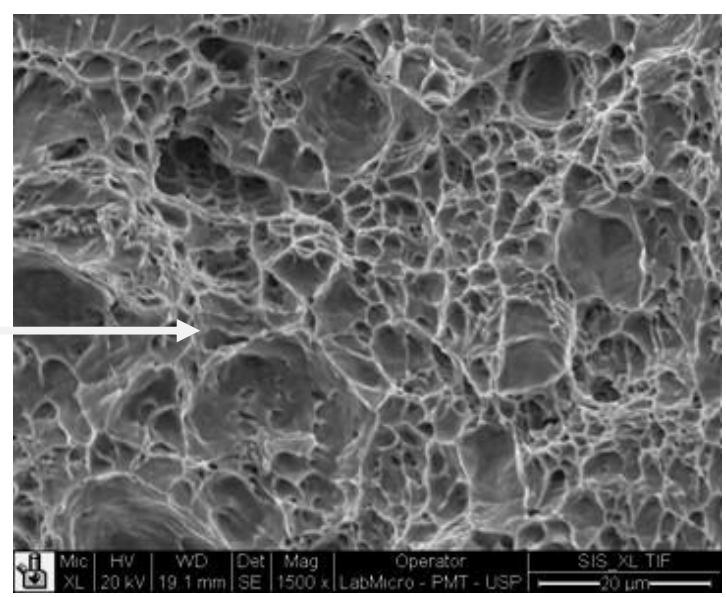

(b) Crack initiation

\footnotetext{
* Contribuição técnica ao $69^{\circ}$ Congresso Anual da ABM - Internacional e ao 14ํㅡㄹ ENEMET - Encontro Nacional de Estudantes de Engenharia Metalúrgica, de Materiais e de Minas, 21 a 25 de julho de 2014, São Paulo, SP, Brasil.
} 


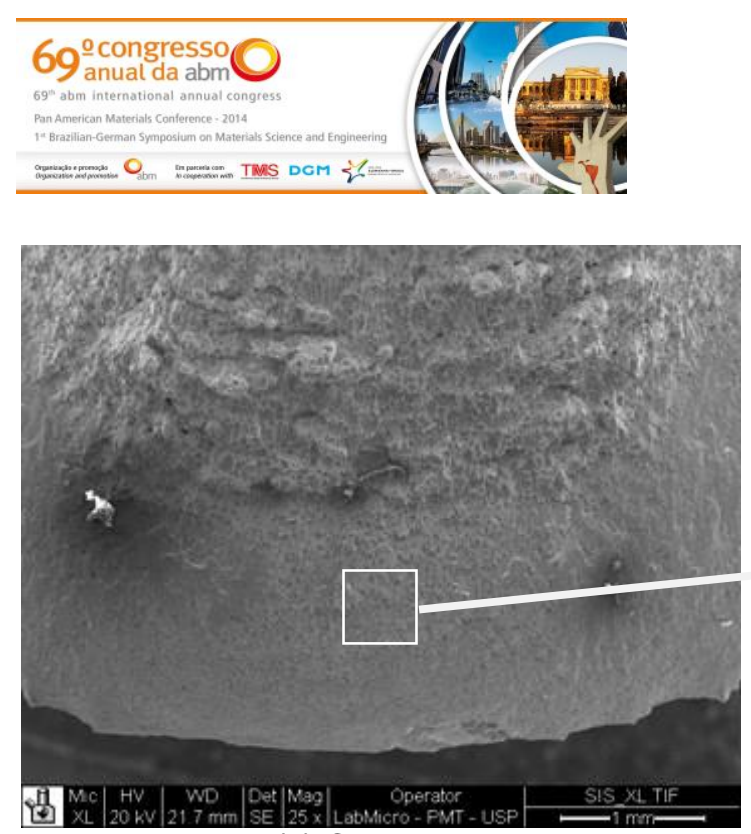

(c) Crack end

Figure 11. Subsize test specimens after the Charpy Impact test. $0^{\circ} \mathrm{C}$.

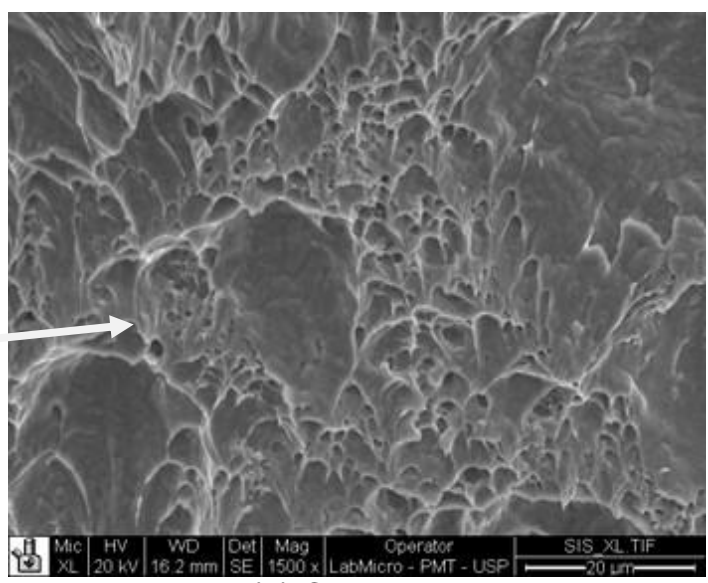

(d) Crack end

\subsection{Tensile Tests}

The tensile test specimens were carried out in both the longitudinal and transverse directions and were machined according to standard API 5L-2004 with subsize measures. The mechanical properties measured on transverse and longitudinal direction (Table 3 ) are consistent with the values required by the standard API $5 \mathrm{~L}$ 2004 for API 5L grade X70 grade pipe (Table 2).

Table 3. Tensile strength (TS) and yield strength (YS) average obtained on the coil on transverse and longitudinal direction.

\begin{tabular}{lcc} 
& Transverse & Longitudinal \\
\hline \hline YS (MPa) & $551 \pm 3$ & $515 \pm 6$ \\
\hline TS (MPa) & $598 \pm 14$ & $596 \pm 10$ \\
\hline $\mathrm{E}(\mathrm{GPa})$ & $220 \pm 6$ & $195 \pm 5$ \\
\hline YS/TS Ratio & 0,92 & 0,87 \\
\hline $\begin{array}{l}\text { Percent total elongation } \\
(\%)\end{array}$ & 31,2 & 35,1 \\
\hline \hline
\end{tabular}

Figure 12 show the fracture surface after the tensile strength test. The presence of dimples on all fracture area reflects the ductility of steel.

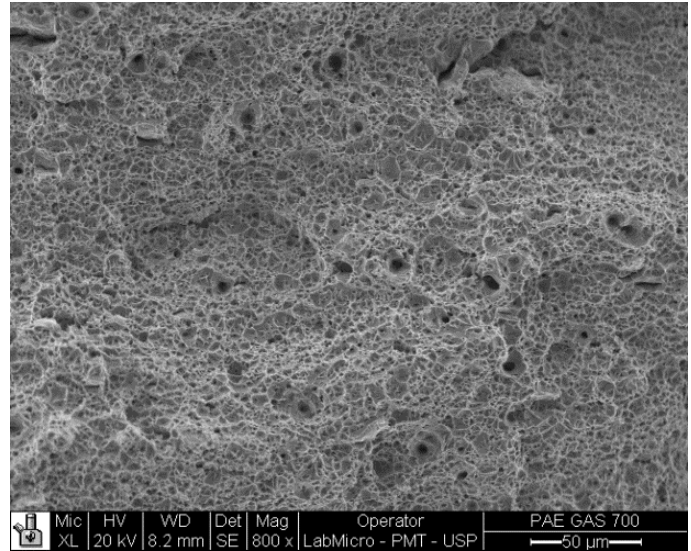

(a)

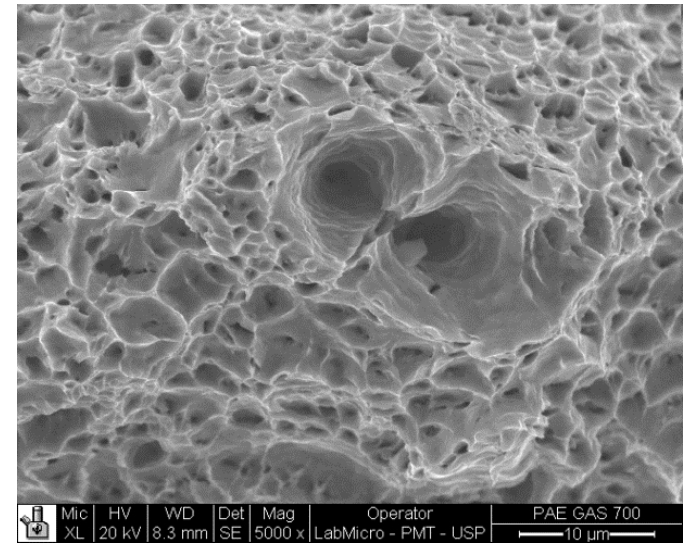

(b)

Figure 12. Fracture surface after the tensile strength test. Transverse sample. SEM.

\footnotetext{
* Contribuição técnica ao $69^{\circ}$ Congresso Anual da ABM - Internacional e ao 14ํㅡㄹ ENEMET - Encontro Nacional de Estudantes de Engenharia Metalúrgica, de Materiais e de Minas, 21 a 25 de julho de 2014, São Paulo, SP, Brasil.
} 


\section{DISCUSSION}

This new low Mn microalloyed steel contained a uniform through thickness microstructure of quasi-polygonal, fine grains of ferrite $(\sim 7 \mu \mathrm{m})$ with few small islands of eutectoid aggregates (ferrite+cementite), and very low volume fraction of homogeneously distributed MA constituent. A characteristic feature of the microstructure was the absence of banded structures, the small number of round shaped and refined inclusions and the absense of centerline segregation; these features suggest that the desired conditions to increase the HIC resistance were achieved. The presence of a very fine and low volume fraction of MA microconstituent $(\mathrm{Vf}=1.1 \pm 0.2)$, located primarily at ferrite grain boundaries appears to have provided beneficial resistance to hydrogen induced cracking.

The small dark regions detected at high magnification at the centerline are believed to be related to the presence of precipitates within the ferrite grains. Those dispersed nano-precipitates are not believed to be critical because their nanometer size helps the distribution of absorbed hydrogen in the microstructure in the presence of $\mathrm{H}_{2} \mathrm{~S}$, preventing stress concentrations [13]. The centerline variation in hardness was insignificant compared the matrix hardness of $188 \pm 6 \mathrm{HV} 0.3$, thus preventing stress accumulation which interacts with hydrogen in these regions. The low hardness of the centerline indicates the general absence of eutectoid aggregates colonies and/or of martensite. The EDS line scans were evidence of the uniform concentration of chemical elements on centerline region of the coil.

The observation of transverse sections of specimens submitted to HIC test did not detect any crack. The following factors are believed to have enhanced resistance to hydrogen induced cracking:

a- Ferrite grain without aligned bands of eutectic aggregates and martensite $[4,13]$.

b- Few islands of eutectoid aggregates, randomly distributed

c- Few and refined precipitates $(2 \mu \mathrm{m}<)$ of $\mathrm{Nb}-\mathrm{Ti}(\mathrm{C})$ and inclusions smaller than $5 \mu \mathrm{m}$ with globular shape, randomly distributed in the ferrite matrix.

The appropriate values of tensile strength and yield strength measured on transverse and longitudinal direction (Table 3) and the high average absorbed energy in the Charpy test easily satisfied the minimum requirements for this steel upto and including API 5L grade X70 (Table 2).

The Charpy impact test with $\mathrm{V}$-notch at $0^{\circ} \mathrm{C}$ surpassed the minimum absorbed energy required by the API 5L-2004 standard for test specimens on tranverse direction. The average absorbed energy was $338 \pm 30 \mathrm{~J}$ (full size equivalent values), higher than energy required which demonstrates the benefits of the very fine ferritic microstructure formed by quasi-polygonal refined grains of ferrite have good capacity to deform plasticaly and consequently retain more hydrogen before cracking.

The plastic deformation showed by the fracture section boundary in all Charpy test specimens corroborate the high energy absorbed prior to fracture, as evidenced by the formation of microvoid coalesence dimples nucleated at the fracture surfaces.

The $0.92 \mathrm{YS} / \mathrm{TS}$ ratio on transverse direction did not exceed the $0.93 \mathrm{YS} / \mathrm{TS}$ maximum value stipulated by standard API 5L-2004.

\section{CONCLUSION}

This new low Mn microalloy steel design has provided a unique insight to both effective strengthening, elimination of segregation and control of sulphide inclusions. The microstructure of the coil is formed by quasi-polygonal fine ferrite grains, with

\footnotetext{
* Contribuição técnica ao 69 Congresso Anual da ABM - Internacional e ao 14ํㅡㄹ ENEMET - Encontro Nacional de Estudantes de Engenharia Metalúrgica, de Materiais e de Minas, 21 a 25 de julho de 2014, São Paulo, SP, Brasil.
} 
absence of banded structures, few small islands of eutectoid aggregates, small number of round shaped, refined inclusions and has been approved in HIC testing according to NACE standards TM0284-2003 without any sign of cracking. The new low Mn alloy design provides the opportunity to produce very high API grades standards where severe sour service resistance is required.

\section{Acknowledgements}

Companhia Brasileira de Metalurgia e Mineração (CBMM); Laboratório de transformações de Fase (LTF-EPUSP); Laboratório de Processos Eletroquímicos (LPE-EPUSP); Instituto de Pesquisas Tecnológicas (IPT); Laboratório de Mecânica dos Sólidos (LMS-EPUSP).

\section{REFERENCES}

1 Nieto J, Elías T, López G, Campos G, López F, De AK. Process and Quality Controls for Production of Linepipe Slabs for Sour Service Applications at. Microalloyed Steel Sour Serv. - Int. Semin. São Paulo, Brasil.; 2012. p. 8.

2 Gray JM. Low Manganese Sour Service Linepipe Steel. Sour Serv. Int. Semin. CBMM Univ. São Paulo- Dep. Eng. Met. e Mater. São Paulo, Brasil.; 2012. p. 16.

3 Subramanian S, Zurob H, Gray JM. Studies on Softening Kinetics of Low Manganese Steel Microalloyed with Niobium for High-Strength Sour Service ERW Pipe. :2011.

4 González MF, Okamoto MA, Oliveira MP , Goldenstein H. Damages Originates by Hydrogen in microalloyed Steel Plate and Pipes in Agriment to API 5L X65 and X80. Rio Pipeline Conf. Expo. Rio de Janeiro, Brasil; 2011. p. 1-10.

5 Al-Mansour M, Alfantazi AM, El-boujdaini M. Sulfide stress cracking resistance of APIX100 high strength low alloy steel. Mater. Des. Elsevier Ltd; 2009 Dec;30(10):4088-94.

6 International NTCS. Standard Test Method Evaluation of Pipeline and Pressure Vessel Steels for Resistance to Hydrogen-Induced Cracking. ANSI/NACE Stand. TM0284. 2003; 21215.

7 International A. Standard Test Methods and Definitions for Mechanical Testing of Steel Products A370-09a. United State; 2009 p. 1-47.

$8 \mathrm{Li}$ Y, Baker TN. Effect of morphology of martensite-austenite phase on fracture of weld heat affected zone in vanadium and niobium microalloyed steels. Mater. Sci. Technol. 2010 Sep 1; 26(9): 1029-40.

9 Shin S, Hwang B, Lee S, Kim N, Ahn S. Correlation of microstructure and charpy impact properties in API X70 and X80 line-pipe steels. Mater. Sci. Eng. A. 2007; 458(1-2): 281-9.

10 Zajac S, Schwinn V, Tacke KH. Characterisation and Quantification of Complex Bainitic Microstructures in High and Ultra-High Strength Linepipe Steels. Mater. Sci. Forum. 2005; 500-501: 387-94.

11 Sha QY. Transformation Characteristics of M-A Constituents in Nb-Ti Microalloyed, Low-Mn Steel and Their Effect on Mechanical Properties. Mater. Sci. Technol. 2008;1337-47.

12 González RM, Goldenstein H, Landgraf JFG, Gorni AA, González Ramírez MF, Landgraf FG. Caracterización y Análisis de la Evolución del Microcontituyente MA en aceros Microaleados para Tubo API X80 Tratado Térmicamente. Cibim9. Islas Canarias, España; 2009; 60-67. http://cibim9.feibim.org/images/stories/libroactas/12Materiales_y_metalurgia.pdf

13 Beidokhti $\mathrm{B}$, Dolati $\mathrm{A}$, Koukabi $\mathrm{AH}$. Effects of alloying elements and microstructure on the susceptibility of the welded HSLA steel to hydrogen-induced cracking and sulfide stress cracking. Mater. Sci. Eng. A. 2009; 507(1-2): 167-73

\footnotetext{
* Contribuição técnica ao $69^{\circ}$ Congresso Anual da ABM - Internacional e ao 14ํㅡㄹ ENEMET - Encontro Nacional de Estudantes de Engenharia Metalúrgica, de Materiais e de Minas, 21 a 25 de julho de 2014, São Paulo, SP, Brasil.
} 